Sains Malaysiana 49(2)(2020): 429-437

http://dx.doi.org/10.17576/jsm-2020-4902-22

\title{
Nasal Fibroblast Conditioned Medium Promotes Cell Attachment and Migration of Human Respiratory Epithelium
}

(Medium Terkondisi Fibroblas Hidung Menggalakkan Perlekatan dan Migrasi Sel Epitelium Pernafasan)

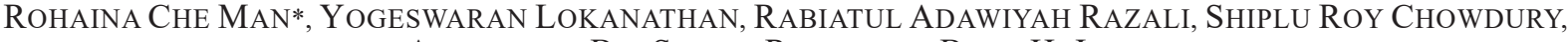 \\ AMINUDDIN BIN SAIM \& RUSZYMAH BINTI HJ IDRUS
}

\begin{abstract}
Endoscopic sinus surgery (ESS) is a well-known surgical treatment for chronic rhinosinusitis disease after failed medical and antibiotics treatment. However, improper wound healing might induce synechiae or adhesion. Conditioned medium from cultured cells is known to promote wound healing and potentially able to accelerate wound healing in ESS and other airway epithelial injuries. This study was to investigate the effect of human nasal fibroblast conditioned medium on the attachment, proliferation and migration of respiratory epithelial cells (RECS) in an in vitro model. RECs and fibroblasts were co-cultured in Defined Keratinocytes Medium and F-12 and Dulbecco's Modified Eagle's Medium. Once confluent, the fibroblasts were removed, leaving the colonies of RECs to reach confluency. RECs and fibroblasts were cultured separately and the conditioned medium was acquired by culturing fibroblast either in DKSFM or F12: DMEM, denoted as NFCM_DKSFM and NFCM_FD, respectively. RECs were supplemented with $20 \%$ conditioned medium for attachment, proliferation and migration assay. The results showed significantly higher cell attachment in NFCM

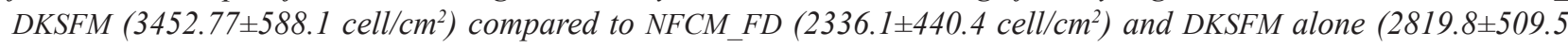
cell $\left./ \mathrm{cm}^{2}\right)$. After 7 days, the specific growth rate was higher in DKSFM $\left(0.019 \pm 5.16 \times 10^{-4} \mathrm{~h}^{-1}\right)$ compared to NFCM_DKSFM $\left(0.015 \pm 8.94 \times 10^{-4} h^{-1}\right)$ and $N F C M_{-} F D\left(0.013 \pm 1.03 \times 10^{-3} h^{-1}\right)$. The mean of migration rate was significantly higher in NFCM_DKSFM $\left(4341.81 \pm 385.7 \mathrm{\mu m}^{2} / \mathrm{hr}\right)$ compared to NFCM_FD $\left(1803.38 \pm 408.1 \mu^{2} / \mathrm{hr}\right)$ and DKSFM $(1933.48 \pm 271.9$ $\left.\mu \mathrm{m}^{2} / \mathrm{hr}\right)$. Hence, NFCM_DKSFM supplementation provides suitable culture conditions for RECs through increased cell attachment and migration, which suggest that the factors secreted in conditioned medium may play a major role in enhancing airway epithelial wound healing.
\end{abstract}

Keywords: Conditioned culture media; epithelial cells; fibroblast; wound healing

ABSTRAK

Pembedahan sinus endoskopi (ESS) adalah rawatan yang terkenal untuk penyakit rhinosinusitis kronik selepas kegagalan rawatan perubatan dan antibiotik. Walau bagaimanapun, penyembuhan luka yang tidak sempurna boleh menyebabkan synechiae atau lekatan. Medium terkondisi (MT) daripada sel yang dikultur didapati boleh menggalakkan penyembuhan luka dan berpotensi mempercepatkan penyembuhan luka disebabkan oleh ESS dan kecederaan lain pada epitelium saluran pernafasan. Kajian ini adalah untuk mengkaji kesan MT daripada fibroblas hidung manusia untuk perlekatan, percambahan dan migrasi sel epitelium pernafasan (RECs) dalam model in vitro. RECs dan fibroblas telah dibiakkan dalam Defined Keratinocytes Medium (DKSFM) dan F-12 dan Dulbecco's Modified Eagle's Medium (FD). Selepas konfluen, fibroblas ditanggalkan dan koloni RECs terus dikultur sehingga padat. RECs dan fibroblas dibiakkan secara berasingan dan MT diperoleh dengan mengkultur fibroblas sama ada dalam DKSFM atau FD, dengan dilabelkan sebagai NFCM_DKSFM dan NFCM_FD. RECs telah ditambah dengan 20\% medium terkondisi untuk perlekatan, percambahan dan migrasi sel. Keputusan menunjukkan perlekatan sel yang lebih tinggi dalam NFCM_DKSFM $\left(3452.77 \pm 588.1 \mathrm{sel} / \mathrm{cm}^{2}\right)$ berbanding NFCM_FD $\left(2336.1 \pm 440.4 \mathrm{sel} / \mathrm{cm}^{2}\right)$ dan DKSFM sahaja $\left(2819.8 \pm 509.5 \mathrm{sel} / \mathrm{cm}^{2}\right)$. Selepas 7 hari dikultur, kadar pertumbuhan khusus adalah lebih tinggi dalam DKSFM $\left(0.019 \pm 5.16 \times 10^{-4} / \mathrm{jam}\right)$ berbanding NFCM_DKSFM $\left(0.015 \pm 8.94 \times 10^{-4} / \mathrm{jam}\right)$ dan NFCM_FD $\left(0.013 \pm 1.03 \times 10^{-3} / \mathrm{jam}\right)$. Purata kadar migrasi sel jauh lebih

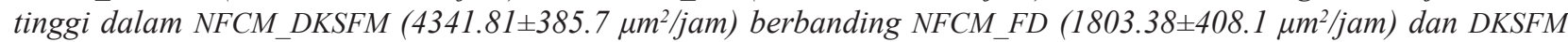
(1933.48 $\left.271.9 \mu \mathrm{m}^{2} / j a m\right)$. Oleh itu, penambahan NFCM_DKSFM menyediakan persekitaran yang sesuai untuk RECs melalui peningkatan perlekatan dan migrasi sel, yang menunjukkan bahawa faktor yang dirembeskan dalam MT boleh memainkan peranan utama dalam meningkatkan penyembuhan luka pada epitelium saluran pernafasan.

Kata kunci: Fibroblas; medium kultur terkondisi; penyembuhan luka; sel epitelium

\section{INTRODUCTION}

The airway epithelium lining functions as a barrier and provides defence against biological, chemical and physical insults. The epithelium plays a significant role in maintaining and regulating innate immune responses to environmental stimuli that cause inflammation and 
epithelial damage (Gropper \& Wiener-Kronish 2008; Shin et al. 2013; Sun et al. 2011; Ware \& Michael 2000; Zahm et al. 1991).

One of the most common diseases of the nose and sinuses is chronic rhinosinusitis (Carroll et al. 2019; Carter et al. 2019; Kim et al. 2019). It has an estimated prevalence of $1 \%-12 \%$ worldwide (Xu et al. 2016). The number is expected to increase due to climate change and pollution. The first line of treatment is still antibiotics, nasal decongestants and nasal douche; however, these treatments do not solve the problem of chronic inflammation and impaired healing of damaged nasal epithelial layer, which can cause pathological changes and later polyps formation. Endoscopic sinus surgery is often used to treat chronic sinusitis, which does not respond to conservative antibiotics treatment. Removal of the damaged epithelium or polyps causes exposure of raw dermis area would lead to scarring, adhesions and possible recurrence of the disease. Several absorbable biomaterials and chemicals are being used, such as hyaluronic acids and synthetic polymer to promote wound healing and prevent adhesion (Fong et al. 2017; Massey \& Singh 2017). However, these materials and chemicals are mainly function as a barrier to prevent adhesion and bleeding, but it is not known to promote epithelial wound healing. Healing of a damaged epithelium requires reparative approaches through the response of wounded cells to a variety of external surrounding cytokines, stimulating factors and growth factors (Zahm et al. 1997). The repair process involves re-epithelialization, which is initiated by cell migration and invasion of neighbouring RECs to restore the damaged surface, followed by cell proliferation and differentiation to improve epithelial barrier integrity (Stripp \& Reynolds 2008; Zahm et al. 1991). Alterations in cytoskeletal protein patterns, binding of growth factors and interactions with extracellular matrix proteins (ECM) and metalloproteinases are able to regulate cell migration in the wounded area (Schultz \& Wysocki 2009). Failure to restore the epithelial barrier may lead to the activation of a massive inflammatory response, contributed to by the colonization of microorganisms and the upregulation of innate and adaptive immune responses (Sun et al. 2011). As of today, the underlying mechanisms involved cell migration and cell proliferation in respiratory epithelial wound healing remain elusive.

Various in vitro experimental studies have been reported to improve wound healing, focusing on the use of secreted factors produced in conditioned medium. A study by Cantinieaux et al. (2013) suggested that the use of bone marrow stem cell conditioned medium (BMSC-CM) to treat spinal cord injury can lead to improved motor recovery. This raises the possibility of developing a cellfree therapeutic approach. Shen et al. (2015) postulated that the paracrine effects of umbilical cord derived mesenchymal stem cells may enhance stem cell-based tissue repair by promoting the specific homing of progenitor cells to the damaged area. An in vitro study by Chowdhury et al. (2012) demonstrated that supplementation with dermal fibroblast conditioned medium (DFCM) significantly enhanced skin keratinocyte expansion by increasing cell attachment and this may be applied in future treatments for skin loss. The fibroblast secretome contains a diverse range of secretory proteins including growth factors, cytokines and ECM proteins (Akram et al. 2014; Chowdhury et al. 2012; Paré et al. 2016). Secretory proteins are known to play a crucial role in many physiological processes (Dowling \& Clynes 2011) including cell attachment, proliferation, cell migration and wound healing (Akram et al. 2013; Chowdhury et al. 2012; Walter et al. 2010). Akram et al. (2014) reported that paracrine factors found in the conditioned medium collected from Activindirected human embryonic stem cells (hESC) differentiated cell significantly enhances airway epithelial cell (AEC) wound repair, through the stimulation of cell migration and proliferation. This report suggested a putative paracrine-mediated epithelial injury healing mechanism by hESC secreted products, which is valuable in the development of novel stem cell-based therapeutic strategies. Akram et al. (2013) also demonstrated that human mesenchymal stem cell-conditioned medium (MSC$\mathrm{CM}$ ) facilitates airway epithelial cell (AEC) and small alveolar epithelial cell (SAEC) wound repair in a serumdependent and independent manner, respectively, by stimulating cell migration. It was found that the hMSC secretome contains an array of proteins, including fibronectin, lumican, periostin, and insulin-like growth factor-binding protein 7 (IGFBP-7), which are capable of influencing AEC and SAEC migration and wound repair. In addition, hMSC also stimulate a strong migratory response in AEC, supported by the observation of rapid and effective AEC wound gap closure by hMSC in a 3D model. All these studies have shown that the secretome from hESC, skin fibroblast dan hMSC are feasible to be used for in in vitro wound healing. However, the effects of nasal fibroblast secretome on wound healing of airway epithelium still has not been extensively studied.

Therefore, in this study, we performed and investigated the effect of the nasal fibroblast conditioned medium on the attachment, proliferation and migration rate of monolayer cultures of RECs using an in vitro wound healing model (scratch assay).

\section{MATERIALS AND METHODS}

\section{NASAL TURBINATE TISSUE ISOLATION AND CELL CULTURE}

This study was approved by the Universiti Kebangsaan Malaysia Research and Ethics Committee, with the approval code: FRGS/1/2016/SKK08/UKM/03/1. All redundant nasal turbinate tissues were obtained from both consenting male and female patients $(n=6)$, with age ranging from 27 to 56 years old, who underwent turbinectomy procedures. In this study, each patient was randomly selected and they have an equal chance or probability of suffering from associated underlying 
respiratory disease, such as turbinate hypertrophy, allergic rhinitis, vasomotor rhinitis or secondary atrophic rhinitis. The tissues were then processed within $24 \mathrm{~h}$ after sample collection. Briefly, the tissues were washed three times with Dulbecco's phosphate buffered saline (DPBS) (Sigma Aldrich, UK), cut into $1 \mathrm{~mm}^{3}$ pieces and digested in $0.6 \%$ collagenase type I (Worthington, USA) solution for about 1.5-2 $\mathrm{h}$, until the tissue digestion is visibly complete. After digestion, the cell suspension containing fibroblasts and RECs was centrifuged at $2370 \mathrm{~g}$ for $5 \mathrm{~min}$. The cell pellet was washed and centrifuged again. The mixture of RECs and fibroblasts was cultured in Defined Keratinocyte Serum Free Medium (DKSFM) (Gibco, USA) and a 1:1 mixture of Ham's F-12: Dulbecco's Modified Eagle's Medium (DMEM) (FD) (Gibco, USA) supplemented with $10 \%$ fetal bovine serum (Biowest, USA) (F: D $+10 \% \mathrm{FBS})$ at $37^{\circ} \mathrm{C}$ in a $5 \% \mathrm{CO}_{2}$ atmosphere. Once confluent, the fibroblasts were removed by differential trypsinization, leaving colonies of RECs in the culture dish to reach confluency in DKSFM.

\section{CELL CHARACTERIZATION: GENE EXPRESSION} ANALYSIS BY QUANTITATIVE RT-PCR

Total purification of RNA from RECs was obtained using the ready-to-use RNeasy Plus Mini Kit (Qiagen, USA) according to the manufacturer's recommendations for cultured cells. This isolated RNA was then subjected to quantitative real time polymerase chain reaction (qPCR) using $\mathrm{iQ}^{\mathrm{TM}}$ SYBR Green Supermix (Biorad, USA). The genes of interest were MUC5B, CK14, CK18 and Ki67. The expression of the housekeeping gene, glycerylaldehyde3-phosphate dehydrogenase (GAPDH) was also used as a loading control for data normalization (Mori et al. 2008). The primer sequences are listed in Table I.

\section{IMMUNOCYTOCHEMICAL ANALYSIS}

Monoclonal antibodies against protein markers of interest were used (acetylated $\beta$-tubulin; Sigma-Aldrich, USA, Cat. No: T6793; 1:2000), CK14 (Abcam, Cat. No: ab51054; 1:100), MUC5AC (Abcam, Cat. No: ab3649; 1:100) and Ki67 (Abcam, Cat. No: ab16667; 1:250). Cultured RECs in 12 -well plates were immunostained as previously described (Walter et al. 2010). Alexa Fluor 488 goat antirabbit IgG (Invitrogen) and Alexa Fluor 594 goat antimouse (Invitrogen) were used as the secondary antibodies. Stained cells were observed using a Nikon Eclipse Ti fluorescence confocal microscopy system (Nikon, Japan) and the images were processed using NIS-Elements Viewer 3.20 software (Nikon, Japan).

\section{COLLECTION OF CONDITIONED MEDIUM}

Fibroblasts (P3) were cultured in FD $+10 \%$ FBS until confluent. Then, the cells were washed with DPBS and cultured in flask either in DKSFM or serum-free FD for another three days. The waste medium was collected and designated as NFCM_DKSFM and NFCM_FD, respectively. DKSFM was used as a positive control throughout the study.

EFFECT OF CONDITIONED MEDIUM ON CELL ATTACHMENT, PROLIFERATION AND MIGRATION IN RECS CULTURE

RECs at P0 were trypsinized and seeded onto 12-well plate with a seeding density of $4 \times 10^{4}$ cells per well. Cell attachment and proliferation were assessed on RECs cultured in DKSFM supplemented with $20 \%$ conditioned medium, at Day 1, Day 3, Day 5 and Day 7, whereas RECs cultured in DKSFM was served as control. Photomicrographs were captured at different intervals using $a$ digital camera and the attached cells were counted manually. Cell counting after $24 \mathrm{~h}$ of cell seeding indicated the cell attachment rate. Furthermore, the morphology of RECs under different culture conditions was observed under inverted microscope. Observation was performed after the cells were washed with DPBS and fresh medium supplemented with conditioned medium was added as described above, in order to eliminate debris and floating cells. Next, the migration rate was assessed using the wound healing assay to evaluate the effects of different conditioned medium on in vitro wound healing. Confluent RECs were centrally scratched using $1 \mu \mathrm{L}$ pipette tips (Eppendorf, Germany), washed three times with DPBS and cultured in DKSFM medium supplemented with $20 \%$ conditioned medium. Cells grown only in DKSFM served

TABLE 1. Genes and the sequences that were used for cell characterization by quantitative real time polymerase chain reaction analysis

\begin{tabular}{|c|c|c|c|}
\hline Genes & Product Size (bp) & Accession No. & Sequences \\
\hline GAPDH & 217 & ВC020308 & $\begin{array}{l}\text { F: TCC CTG AGC TGA ACG GGA AG } \\
\text { R: GGA GGA GTG GGT GTC GCT GT }\end{array}$ \\
\hline CK18 & 152 & NM_000224 & $\begin{array}{l}\text { F: CTG AGG TTG GAG CTG CTG AGA } \\
\text { R: CTG CTC CAT CTG TAG GGC GTA }\end{array}$ \\
\hline CK14 & 150 & ВC002690 & $\begin{array}{l}\text { F: AGA ACC GCA AGG ATG CCG AG } \\
\text { R: CCT GGA GAT TGA GCT GCA GT }\end{array}$ \\
\hline MUC5B & 150 & U95031 & $\begin{array}{l}\text { F: GTC AAC AGC CAT GTG GAC AAC } \\
\text { R: CTC CTC ACA GGA GTA GCA GCA }\end{array}$ \\
\hline Ki67 & 202 & NM_002417 & $\begin{array}{l}\text { F: GGC CTC ACA GGA GTA GCA GCA } \\
\text { R: GCT GAC TGC TAG GGG CTC TTC }\end{array}$ \\
\hline
\end{tabular}


as the positive control. REC wound closure under different culture conditions was recorded using the time-lapse imaging tool on the Nikon Eclipse Ti fluorescence microscope, with an interval of $20 \mathrm{~min}$, for up to $72 \mathrm{~h}$. The scratched area was then analyzed using NIS-Elements Viewer 3.20 software.

\section{STATISTICAL ANALYSIS}

The data obtained for cell attachment, proliferation and migration were analyzed using the SPSS software package version 16.0 (SPSS Inc., USA). One-way ANOVA was used to determine any statistically significant differences between the groups. A $p$ value of less than 0.05 was considered statistically significant.

\section{RESULTS}

\section{MORPHOLOGICAL FEATURE OF THE PRIMARY CELLS}

Mixed culture of RECs and fibroblast was obtained from nasal turbinate samples. Co-cultured cells were differentially trypsinized, leaving the RECs colonies to reach $70-80 \%$ confluency. At this point, epithelial cells in primary culture were dense and uniformly grew in polygonal shapes, with $76.67 \pm 3.53 \%$ cell viability (Figure $1(\mathrm{~A})$ ).

\section{CELL CHARACTERIZATION BY GENE AND PROTEIN} EXPRESSION

The qPCR analysis showed expression of all four genes of interest, namely MUC5B, CK14, CK18 and Ki67 by RECs (data not shown). Immunocytochemical analysis showed positive staining for acetylated $\beta$-tubulin, CK14 and MUC5AC in the cytoplasm, whereas the cell proliferation marker, Ki67 was positively localized in nucleus of RECs (Figure 1(B)). The positive expression of all markers indicated that the cells were RECs and were actively proliferating.

\section{EFFECT OF NFCM ON CELL ATTACHMENT, PROLIFERATION AND MIGRATION}

Supplementation of RECs with NFCM_DKSFM led to significantly greater cell attachment $(3452.77 \pm 588.1$ cells/ $\left.\mathrm{cm}^{2}\right)$ compared to NFCM_FD $\left(2336.1 \pm 440.4\right.$ cells $\left./ \mathrm{cm}^{2}\right)$, although the mean of NCFM_DKSFM was not significant compared to that of control group (DKSFM) (2819.8 \pm 509.5 cells $/ \mathrm{cm}^{2}$ ) (Figure 2). Based on this result, the analysis indicated that the secretory products provided by NFCM DKSFM did not have a significant effect on the RECs culture, as the cells grown in NFCM_DKSFM showed almost equivalent levels of cell attachment compared to that of control group (DKSFM). In comparison to the cells cultured in NFCM_FD, both NFCM_DKSFM and DKSFM led to an improvement in cell attachment. In contrast, the growth rate was significantly higher in DKSFM $\left(0.019 \pm 5.16 \times 10^{-4} \mathrm{~h}^{-1}\right)$ compared to NFCM_DKSFM $\left(0.015 \pm 8.9 \times 10^{-4} \mathrm{~h}^{-1}\right)$ and NFCM_FD $\left(0.013 \pm 1.03 \times 10^{-3} \mathrm{~h}^{-1}\right)$ (Figure 3(A) and 3(B)). The wound healing assay showed that RECs in NFCM_DKSFM underwent significantly faster migration into the scratched area with a mean migration rate of $4341.81 \pm 385.7 \mu \mathrm{m}^{2} / \mathrm{h}$ compared to other two conditions, NFCM_FD $\left(1803.38 \pm 408.1 \mu \mathrm{m}^{2} / \mathrm{h}\right)$ and DKSFM $\left(1933.48 \pm 271.9 \mu \bar{m}^{2} / h\right)$ (Figure 2(D)). The RECs migrated slowest in NFCM_FD as it took approximately $68 \mathrm{~h}$ to close the gap.

\section{DISCUSSION}

Cells that were cultured in different types of growth media have the potential to secrete a number of proteins, including cytokines, chemokines and growth factors, into the surrounding culture environment (Kulasingam \& Diamandis 2007; Shin et al. 2013; Thorsell et al. 2008; Walter et al. 2010). These secreted factors are known to promote the rapid migration of cells, followed by cell proliferation both in culture and in vivo (Chowdhury et al. 2012; Walter et al. 2010). There have been many identified molecules released into the medium by fibroblasts, including plasminogen activator (Ossowski \& Reich 1983), collagen (Goldberg \& Green 1964), collagenase (Chua et al. 1985), elastin (Padma \& Bhat 2017), thrombospondin (Jaffe et al. 1983) and laminin (Fried et al. 2005).

To date, no study has assessed the secretome from human nasal turbinate cells in a wound healing model and the future use of this conditioned media as a cell-free therapy. In this study, we investigated the efficacy of conditioned medium in terms of enhancing the attachment, proliferation and migration of RECs in vitro. Our study shows that the proteins secreted in NFCM_DKSFM may have a role in improving RECs attachment and migration, whereas in the context of proliferation, the number of cells grown in NFCM_DKSFM was slightly increased compared to the control medium, DKSFM. In contrast, cells grown in NFCM_FD in which cell numbers decreased over time, compared to DKSFM and NFCM_DKSFM. This may be due to the presence of high amount of lactate and ammonia, which are known to cause decreased cell growth and growth arrest (Slivac et al. 2010). The attachment and proliferation of cells is also promoted by surface coating with extracellular matrix proteins such as fibronectin and collagen. The observed enhanced cell attachment in NFCM_DKSFM compared to NFCM_FD indicated that NFCM_DKSFM may contain a higher concentration of ECM proteins than NFCM_FD. Besides that, NFCM_FD contain calcium which is known to decrease epithelial cell attachment (Ghani et al. 2016). The supplementation of NFCM_DKSFM increased the efficiency of cell attachment by autologous skin keratinocytes, in correlation with the study by Chowdhury et al. (2012). Dermal fibroblasts cultured in DKSFM could induce the production of extracellular matrix components that increase the efficiency of cell attachment. There are many ECM proteins in the secretomes, such as laminin subunit gamma 1 (LAMC1), 
A

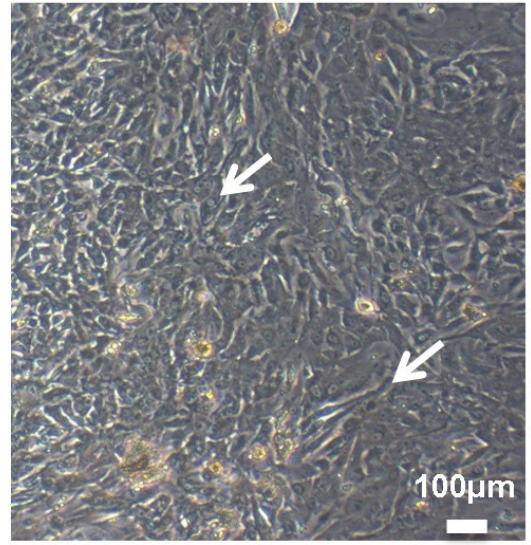

Co-Culture of RECs and Fibroblasts

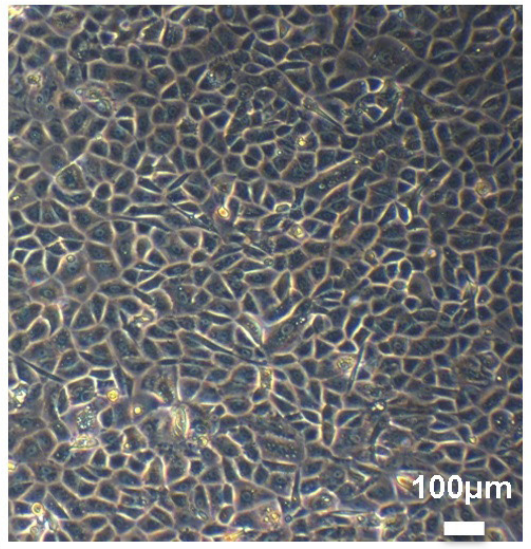

RECS

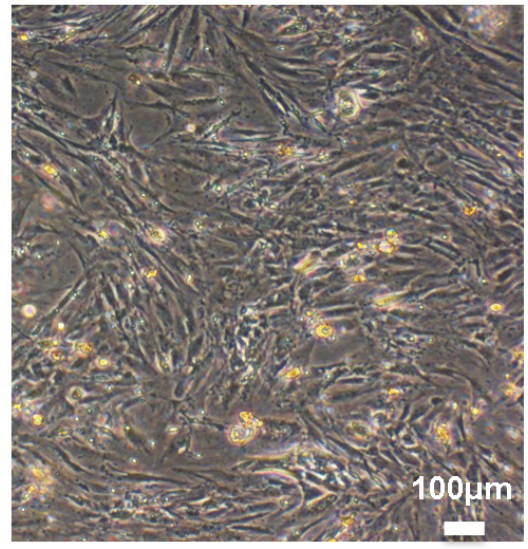

Fibroblasts

B

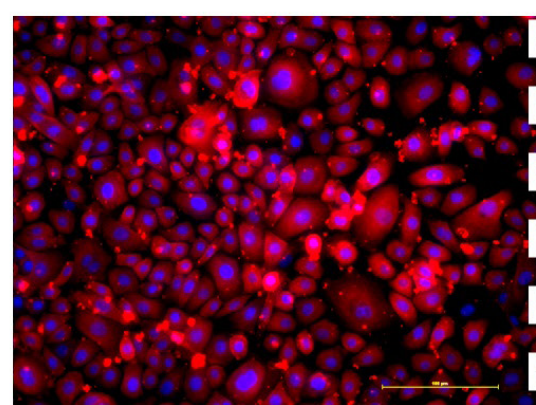

Acetylated $\beta$-tubulin + Nucleus (DAPI)

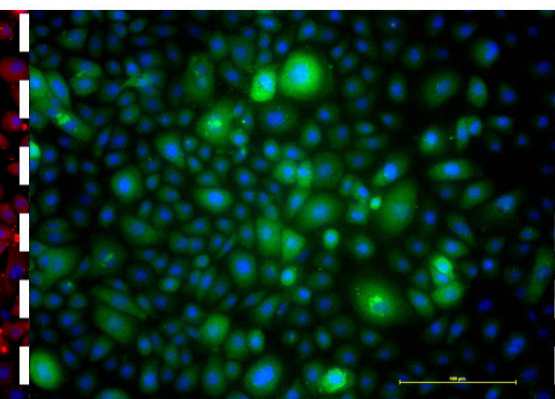

CK14 + Nucleus (DAPI)

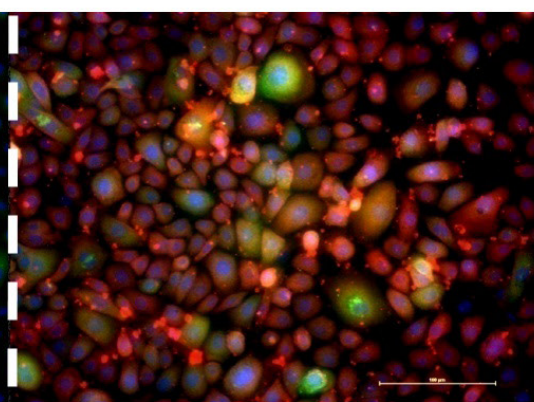

Merge

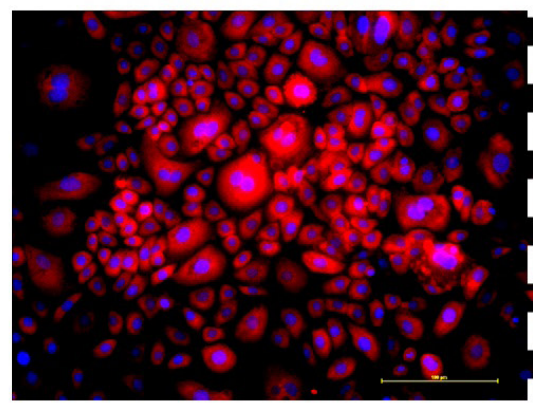

MUC5AC + Nucleus (DAPI)

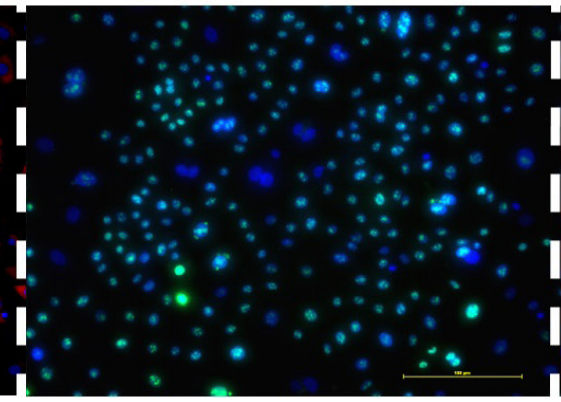

Ki67 + Nucleus (DAPI)

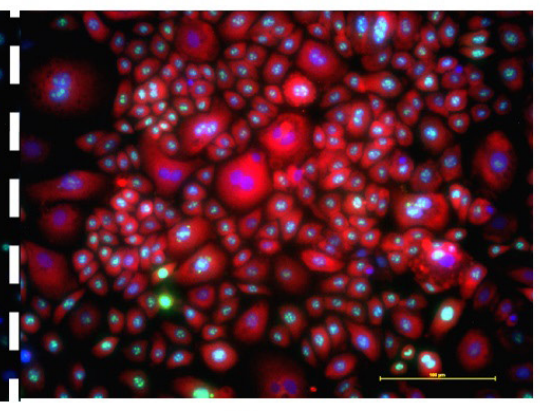

Merge

$100 \mu \mathrm{m}$

FIGURE 1. (A) Morphology of cells in a mixed culture of RECs and fibroblasts (white arrow). After differential trypsinization, RECs in primary culture grew in compact, dense monolayers and were polygonal in shape, with $76.67 \%$ cell viability, whereas nasal fibroblasts had a spindle-like morphology, (B) Cell characterization by immunocytochemical analysis showed positive staining for all four protein markers; three were detected in the cytoplasm (acetylated $\beta$-tubulin, CK14 and MUC5AC) whereas Ki67 was detected in the nucleus

laminin subunit beta 2 (LAMB2), nidogen 1 (NID1), immunoglobulin superfamily containing leucine-rich repeat protein (ISLR) and fibrillin-1 (FBN1). However, the effects of the secretory products in NFCM_DKSFM were not significant in terms of cell attachment when compared to DKSFM alone. Cell proliferation was significantly higher in DKSFM compared to NFCM_DKSFM and NFCM_FD. During wound repair, cell surface adhesion molecules play a key role by modulating cell contact with the extracellular matrix or with neighbouring cells (Aragona et al. 2017; 


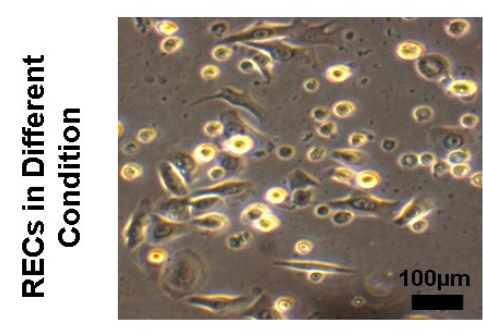

DKSFM

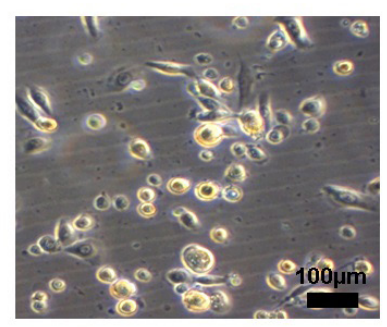

NFCM_DKSFM

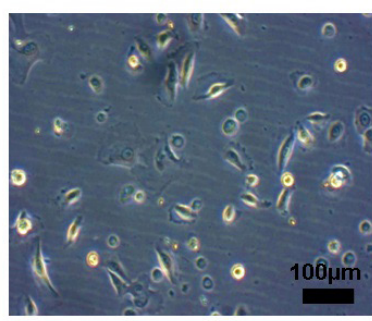

NFCM_FDCM

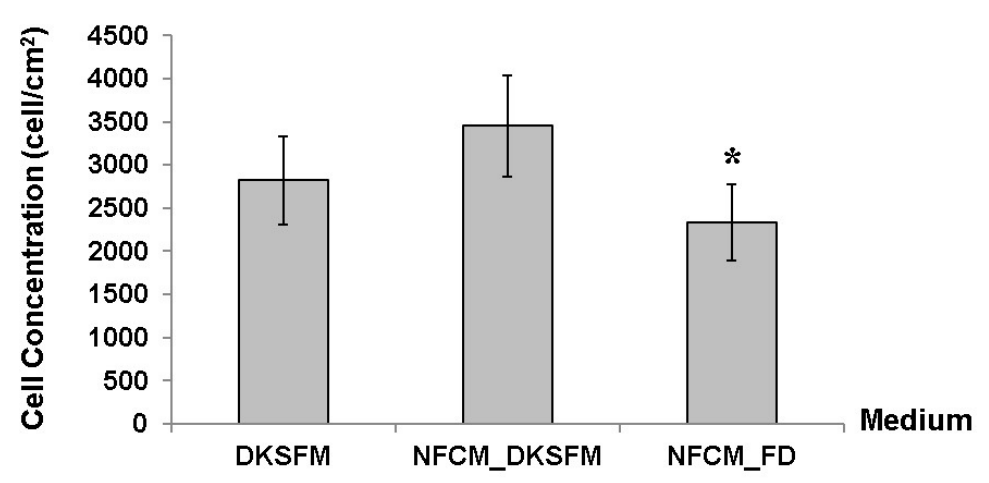

FIGURE 2. The efficiency of cell attachment was recorded $24 \mathrm{~h}$ after cell seeding. Cell numbers were analyzed in triplicate, with four images taken from different points of the well. *NFCM_DK vs NFCM_FD. Values of $p<0.05$ were considered statistically significant $(\mathrm{n}=6)$

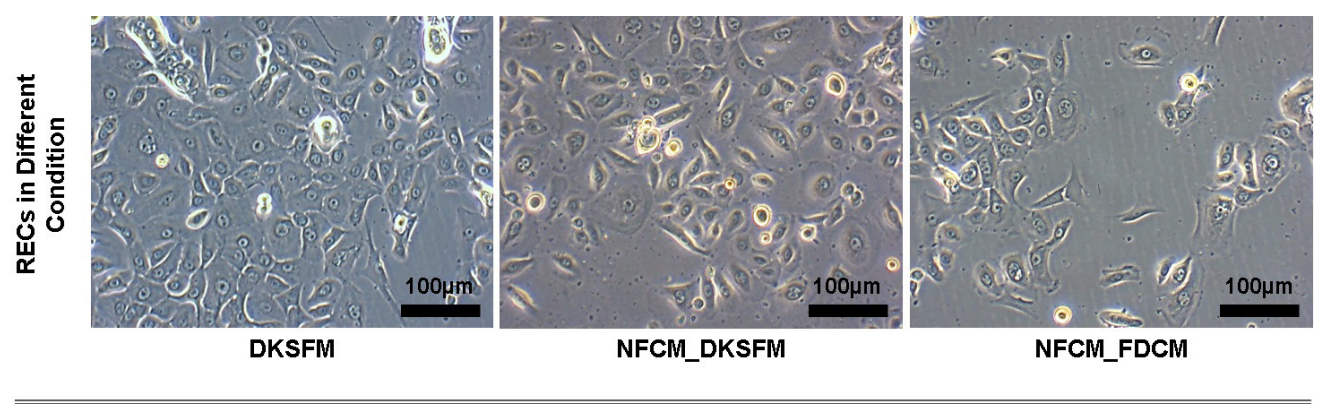

A

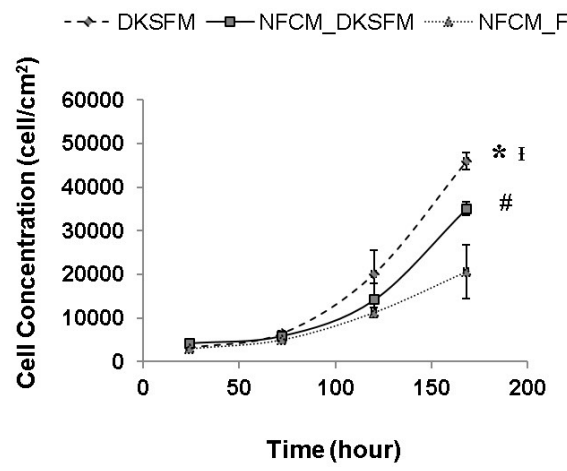

B

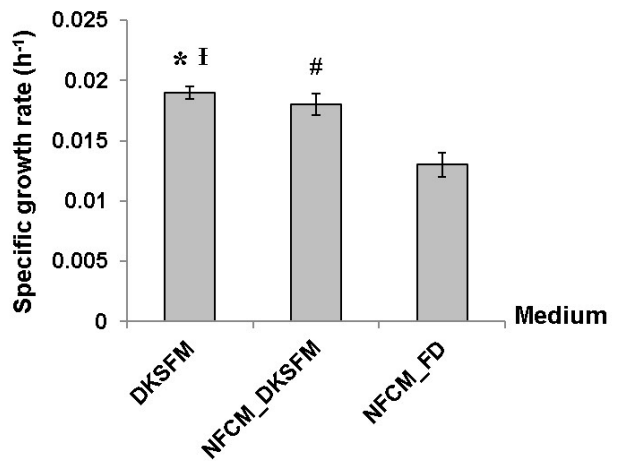

FIGURE 3. Proliferation rate of RECs in different conditions after $72 \mathrm{~h}$ of culture. A: Growth curve of RECs supplemented with three different growth media. *DKSFM vs NFCM_DK, IDKSFM vs NFCM_FD, \#NFCM_DK vs NFCM_FD; B: The growth rate of cultured RECs in three culture conditions. *DKSFM vs NFCM_DK, $¥$ DKSFM vs NFCM_FD, \#NFCM_DK vs NFCM_FD. Values of p $<0.05$ were considered statistically significant $(\mathrm{n}=6)$ 

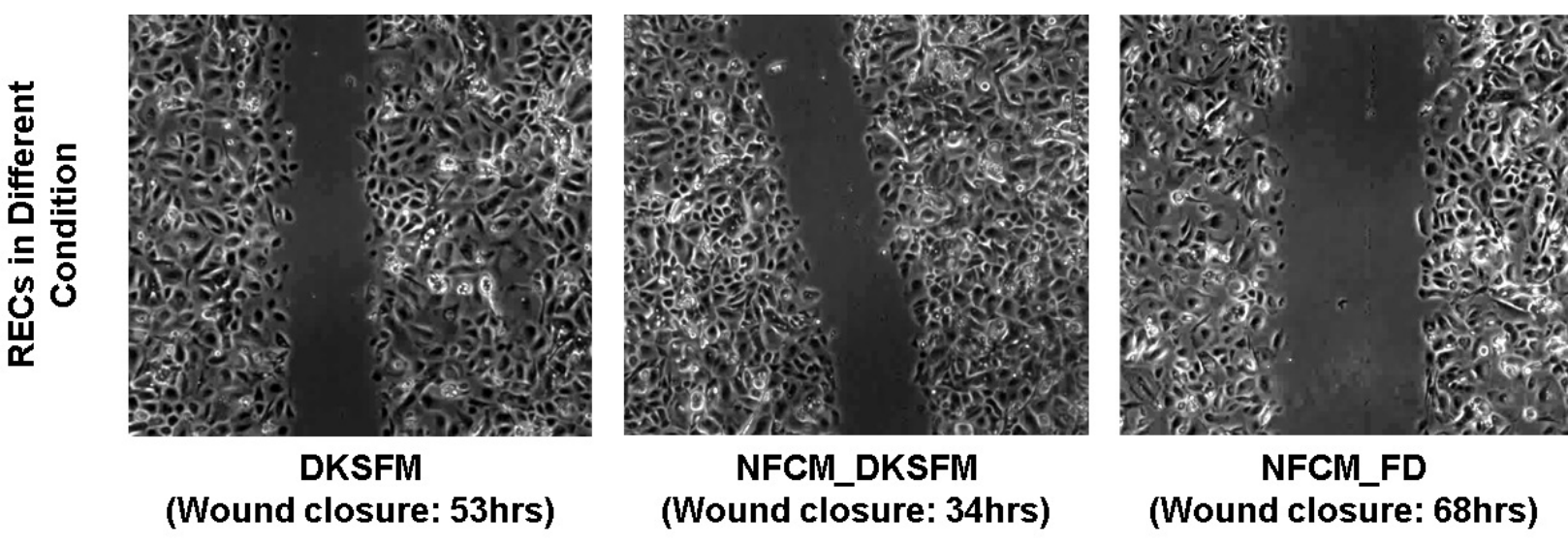

NFCM_DKSFM
(Wound closure: $34 \mathrm{hrs}$ )

(Wound closure: $68 \mathrm{hrs}$ )

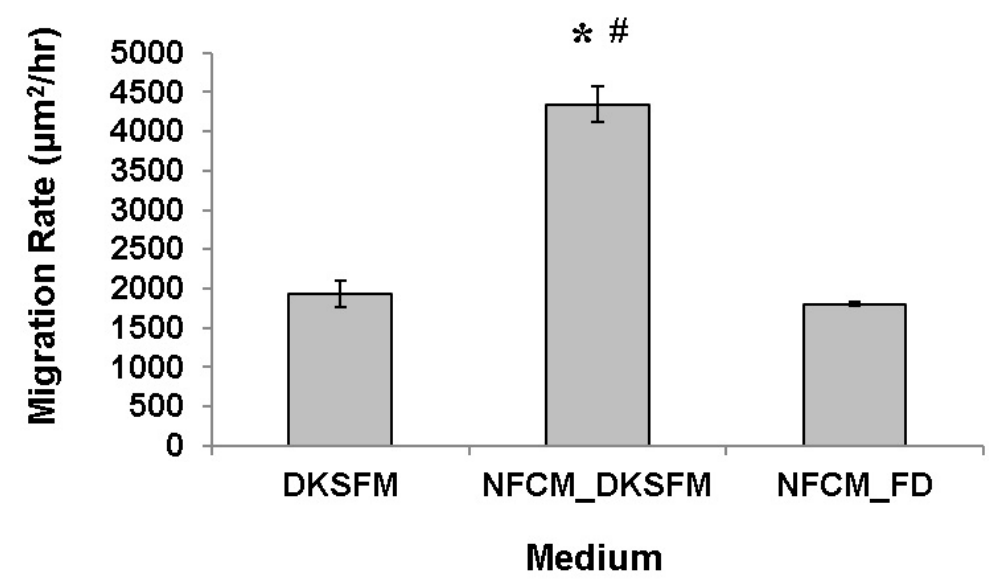

FIGURE 4. Cell migration assay under three culture conditions. Photomicrographs of RECs under different culture conditions were taken immediately after cell wounding, with time-lapse video recordings with an interval of $20 \mathrm{~min}$. *DKSFM vs NFCM_DKSFM, \#NFCM_DKSFM vs NFCM_FD. Values of $\mathrm{p}<0.05$ were considered statistically significant $(\mathrm{n}=6)$

Sahu et al. 2017). Time-lapse video recordings of the progressive closure of the wound suggested that early reepithelialization had occurred by a cell migration process, indicated by an increased migration rate in NFCM_DKSFM. In contrast, cells in NFCM_FD showed slower proliferation and migration rates as compared to those of in other media, suggesting that the secreted proteins in this conditioned medium may have induced cell differentiation, leading to slower cell growth and cell migration. A study reported by Walter et al. (2010) suggested that the use of mesenchymal stem cell derived conditioned medium enhances skin wound closure by affecting the migration of both dermal fibroblasts and keratinocytes, along with a contribution to the formation of extracellular matrix. It has been shown that serum-free mesenchymal stem cell conditioned medium (MSC-CM) significantly enhances the wound closure rate of fibroblasts and keratinocytes, separately and in co-culture, whereas conditioned medium from L929 or $\mathrm{HaCaT}$ cultures had no significant effects on wound closure. This enhancement of wound closure in the presence of MSC-CM was found to be due to accelerated cell migration rather than increased cell proliferation.
These investigators also successfully identified secreted cytokines, chemokines and ECM components including TGF- $\beta 1$, IL-6, IL-8, MCP-1, RANTES, collagen type I, fibronectin, SPARC and IGFBP-7 which may have influenced cell growth and migration. However, in this study, there are two potential limitations that should be noted. The first limitation concerns on the sample variation that includes the age groups, gender and different underlying conditions, which eventually may influence content of the secretome. The second limitation was that the secretome were collected from sample obtained from non-healthy subjects as it was not possible to collect nasal turbinate samples from healthy individuals. Thus, the secretome from unhealthy subject might have some level of difference with that of from healthy subject. The secretome from healthy subject might show a better outcome in promoting epithelial wound healing and also important in translating this discovery into clinical therapies.

Hence, supplementation of NFCM_DKSFM provides suitable culture conditions for RECs through increased cell attachment and migration, which suggest that the factors 
secreted in conditioned medium may play a major role in enhancing airway epithelial wound healing. However, more extensive studies should be done to identify the specific proteins that enhance RECs growth and migration, the proteins upregulated by supplementation with conditioned medium, and also to validate the role of the underlying mechanism predicted to promote wound healing by RECs in this study. Hopefully, these findings will encourage the use of secretomes and derivatives in promoting the regeneration of the nasal epithelium in cases of chronic infection or inflammation and, most importantly, following post sinus surgery.

\section{ACKNOWLEDGEMENTS}

This study was made possible by a UKM research grant from the Ministry of Education Malaysia (DPP-2014-121). The authors have no conflicts of interest to declare.

\section{REFERENCES}

Akram, K.M., Monica, A.S. \& Nicholas, R.F. 2014. Activindirected differentiation of human embryonic stem cells differentially modulates alveolar epithelial wound repair via paracrine mechanism. Stem Cell Discovery 4: 67-82.

Akram, K.M., Sohel, M., Monica, A.S. \& Nicholas, R.F. 2013. Mesenchymal stem cells promote alveolar epithelial cell wound repair in vitro through distinct migratory and paracrine mechanisms. Respiratory Research 14: 9. doi: 10.1186/1465-9921-14-9.

Aragona, M., Sophie, D., Steffen, R., Sandrine, L., Guilhem, M., Benjamin, D.S. \& Cédric, B. 2017. Defining stem cell dynamics and migration during wound healing in mouse skin epidermis. Nature Communications 8: 14684.

Cantinieaux, D., Quertainmont, R., Blacher, S., Rossi, L., Wanet, T., Noël, A., Brook, G., Schoenen, J. \& Franzen, R. 2013 Conditioned medium from bone marrow-derived mesenchymal stem cells improves recovery after spinal cord injury in rats: An original strategy to avoid cell transplantation. PLOS ONE 8: e69515.

Carroll, M.P., Adeeb, A.B. \& Richard, F.L. 2019. Rhinitis and sinusitis. In Asthma, Allergic and Immunologic Diseases During Pregnancy, edited by Namazy, J.A. \& Schatz, M. Switzerland: Springer International Publishing. pp. 61-86.

Carter, A., Nikesh, D. \& Saiful, A.H. 2019. Chronic rhinosinusitis. BMJ 364: 1131.

Chowdhury, S.R., Aminuddin, B.S. \& Ruszymah, B.H.I. 2012. Effect of supplementation of dermal fibroblasts conditioned medium on expansion of keratinocytes through enhancing attachment. Indian Journal of Experimental Biology 50: 332-339.

Chua, C.C., Geiman, D.E., Keller, G.H. \& Ladda, R.L. 1985. Induction of collagenase secretion in human fibroblast cultures by growth promoting factors. Journal of Biological Chemistry 260: 5213-5216.

Dowling, P. \& Martin, C. 2011. Conditioned media from cell lines: A complementary model to clinical specimens for the discovery of disease-specific biomarkers. Proteomics 11: 794-804.

Fong, E., Garcia, M., Woods, C.M. \& Ooi, E. 2017. Hyaluronic acid for post sinus surgery care: Systematic review and meta-analysis. The Journal of Laryngology \& Otology 131: 2-11.

Fried, K., Wondossen, S., Christina, L., Ismo, V., Karl, T. \& Manuel, P. 2005. Laminins $2(\alpha 2 \beta 1 \gamma 1, \mathrm{Lm}-211)$ and 8 $(\alpha 4 \beta 1 \gamma 1, \mathrm{Lm}-411)$ are synthesized and secreted by tooth pulp fibroblasts and differentially promote neurite outgrowth from trigeminal ganglion sensory neurons. Experimental Cell Research 307: 329-341.

Ghani, N.'I., Aminuddin, B.S., Ruszymah, B.H.I. \& Chowdhury, S.R. 2016. Calcium in dermal fibroblast conditioned medium (DFCM) enhance keratinocytes wound healing in vitro. 6th Malaysian Tissue Engineering and Regenerative Medicine Scientific Meeting and 2nd Malaysian Stem Cell Meeting, Nov 17-18, Pulau Pinang, Malaysia.

Goldberg, B. \& Howard, G. 1964. An analysis of collagen secretion by established mouse fibroblast lines. The Journal of Cell Biology 22: 227-258.

Gropper, M.A. \& Jeanine, W.K. 2008. The epithelium in acute lung injury/acute respiratory distress syndrome. Current Opinion in Critical Care 14: 11-15.

Jaffe, E.A., Joseph, T.R., Leung, L.K., Mary, J.D., Paula, J.M.L. \& Deane, F.M. 1983. Cultured human fibroblasts synthesize and secrete thrombospondin and incorporate it into extracellular matrix. Proceedings of the National Academy of Sciences 80: 998-1002.

Kim, D.W., Kyoung, M.E., Eun, Y.R., Sue, S. \& Kim, D.K. 2019. Chronic rhinosinusitis without nasal polyps in Asian patients shows mixed inflammatory patterns and neutrophilrelated disease severity. Mediators of Inflammation 2019: 7138643.

Kulasingam, V. \& Eleftherios, P.D. 2007. Proteomics analysis of conditioned media from three breast cancer cell lines a mine for biomarkers and therapeutic targets. Molecular \& Cellular Proteomics 6: 1997-2011.

Massey, C.J. \& Ameet, S. 2017. Advances in absorbable biomaterials and nasal packing. Otolaryngologic Clinics of North America 42: 813-828.

Mori, R., Qingcai, W., Kathleen, D.D., Jacek, K.P. \& Peter, V.D. 2008 . Both $\beta$-actin and GAPDH are useful reference genes for normalization of quantitative RT-PCR in human FFPE tissue samples of prostate cancer. The Prostate 68: 15551560.

Ossowski, L. \& Reich, E. 1983. Antibodies to plasminogen activator inhibit human tumor metastasis. Cell 35: 611-619.

Padma, D. \& Kumar, M.R.B. 2017. Effect of extracellular matrix produced by the fibroblasts derived from the vitiligo skin on survival and function of melanocytes. Advanced Science Letters 23: 1904-1909.

Paré, B., Lydia, T.D., Roxane, P., Nicolas, D. \& Francois, G.L. 2016. An optimized approach to recover secreted proteins from fibroblast conditioned-media for secretomic analysis. Frontiers in Cellular Neuroscience 10: 107.

Sahu, S., Zhihua, Z., Rong, L., Junkai, H., Huifan, S., Gabriele, L., Yanqin, S. \& Melitta, S. 2017. A small organic compound mimicking the L1 cell adhesion molecule promotes functional recovery after spinal cord injury in zebrafish. Molecular Neurobiology 55: 859-878.

Schultz, G.S. \& Annette, W. 2009. Interactions between extracellular matrix and growth factors in wound healing. Wound Repair and Regeneration 17: 153-162.

Shen, C., Puchang, L., Tianyu, M., Meixing, Y., Qiao, L., Ting, F., Jinrong, L, Tingting, Z., Xiaohuan, L. \& Hong, L. 2015. Conditioned medium from umbilical cord mesenchymal 
stem cells induces migration and angiogenesis. Molecular Medicine Reports 12: 20-30.

Shin, S.H., Ye, M.K., Hwang, Y.J. \& Kim, S.T. 2013. The effect of Asian sand dust-activated respiratory epithelial cells on activation and migration of eosinophils. Inhalation Toxicology 25: 633-639.

Slivac, I., Višnja, B., Kristina, R.ć, Zlatko, K. \& Višnja, G.S. 2010. Influence of different ammonium, lactate and glutamine concentrations on $\mathrm{CCO}$ cell growth. Cytotechnology 62: 585-594.

Stripp, B.R. \& Susan, D.R. 2008. Maintenance and repair of the bronchiolar epithelium. Proceedings of the American Thoracic Society 5: 328-333.

Sun, Y.H., Brian, R., Justin, H.F., Lisa, A.M., Dallas, M.H., Alex, M. \& Min, Z. 2011. Airway epithelial wounds in rhesus monkey generate ionic currents that guide cell migration to promote healing. Journal of Applied Physiology 111: 10311041.

Thorsell, A., Jonas, F., Fredrik, B., Michael, N., Kaj, B., Peter, S.E. \& Ann, W.B. 2008. Proteome analysis of serumcontaining conditioned medium from primary astrocyte cultures. Journal of Proteomics \& Bioinformatics 1: 128142.

Walter, M.N.M., Karina, T.W., Fuller, H.R., Sheila, M. \& Johnson, W.E.B. 2010. Mesenchymal stem cell-conditioned medium accelerates skin wound healing: An in vitro study of fibroblast and keratinocyte scratch assays. Experimental Cell Research 316: 1271-1281.

Ware, L.B. \& Michael, A.M. 2000. The acute respiratory distress syndrome. New England Journal of Medicine 342: 1334-1349.

Xu, Y., Hude, Q., Peter, F., Stephanie, G., Mingfu, L., Ceris, B., Edward, K., Stafford, D. \& Luke, R. 2016. Prevalence and incidence of diagnosed chronic rhinosinusitis in Alberta, Canada. JAMA Otolaryngology-Head \& Neck Surgery 142: 1063-1069.
Zahm, J.M., Hervé, K., Hérard, A.L., Fabrice, D., Denis, P., Pascal, S. \& Edith, P. 1997. Cell migration and proliferation during the in vitro wound repair of the respiratory epithelium. Cell Motility and The Cytoskeleton 37: 33-43.

Zahm, J.M., Pierrot, D., Chevillard, M. \& Puchelle, E. 1991. Dynamics of cell movement during the wound repair of human surface respiratory epithelium. Biorheology 29: 459465.

Rohaina Che Man*, Yogeswaran Lokanathan \& Shiplu Roy Chowdury

Tissue Engineering Centre

Faculty of Medicine

Universiti Kebangsaan Malaysia Medical Centre

Jalan Yaacob Latif, Bandar Tun Razak

56000 Kuala Lumpur, Federal Territory

Malaysia

Rabiatul Adawiyah Razali \& Ruszymah Binti Hj Idrus

Department of Physiology

Faculty of Medicine

Universiti Kebangsaan Malaysia Medical Centre

Jalan Yaacob Latif, Bandar Tun Razak

56000 Kuala Lumpur, Federal Territory

Malaysia

Aminuddin Bin Saim

Ear, Nose \& Throat Consultant Clinic

Ampang Puteri Specialist Hospital

68000 Ampang, Selangor Darul Ehsan

Malaysia

*Corresponding author; email: ruszyidrus@gmail.com

Received: 17 March 2019

Accepted: 30 October 2019 
